УДК 364

DOI:

Леся Рутьян, аспірантка кафедри соціальної реабілітації та соціальної педагогіки Київського національного університету імені Тараса Шевченка

\title{
ІСТОРІЯ I РОЗВИТОК ДОМАШНЬОГО НАСИЛЬСТВА НАД ЖІНКАМ ЯК НАУКОВОГО ПОНЯТТЯ
}

Проведено теоретичний аналіз історичного становлення і розвитку домашнього насильства над жінкам як наукового поняття. Здійснено історичний зріз стосовно виникнення домашнього насильства над жінками. Охарактеризовано розвиток домашнього насильства над жінками. Констатовано, шьо домашнє насильство над жінками є науковим поняттям, яке потребує комплексного вирішення різними галузями, такими як: сочіологія, психологія, педагогіка, філософія, психіатрія.

Описано роль релігійних канонів у формуванні домашнього насильства, які сприяли існуванню суспільних i державних утворень, установок і иінностей, констатовуючи прагнення володіти чоловіка над жінкою. Виділено основні етапи домашнього насильства: першим етапом є виникнення напруги у стосунках; наступним - сам прояв насильства; фінальним - "Медовий місяцьь”.

Ключові слова: насильство; домашнє насильство; домашнє насильство над жінками.

Puc. 2. Лim. 15.

Lesya Rutyan, Postgraduate Student of the Social Rehabilitation and Social Pedagogy Department Kyiv Taras Shevchenko National University

\section{HISTORY AND DEVELOPMENT OF DOMESTIC VIOLENCE AGAINST WOMEN AS A SCIENTIFIC CONCEPT}

The article deals with the theoretical analysis of the historical formation and development of domestic violence against women as a scientific concept. A historical overview of the occurrence of domestic violence against women has been made. The development of domestic violence against women is described. It is stated that domestic violence against women is a scientific concept that needs a comprehensive solution in various fields, such as. sociology, psychology, pedagogy, philosophy, psychiatry. The role of religious canons in the formation of domestic violence is described - it contributed to the existence of social and state formations, attitudes and values, which stated the role of man over woman. Scientific works on the studied phenomenon are generalized and it is emphasized that domestic violence against women is a significant process today, which nullifies social canons, destroys models of mutual understanding, distorts values, causes, and generates mass psychological complexes of inferiority, cruelty, inferiority, cruelty; an obstacle to achieving equality and respect for women's rights in modern society. Violence is considered as a form of social deviation and is defined as a phenomenon of discrimination against a person, oppression or restriction of his rights and freedoms. The main stages of domestic violence are highlighted: the first stage is the emergence of tension in the relationship; the next stage is the very manifestation of violence; the final stage is the "Honeymoon". It is concluded that domestic violence against women is the repeated use of force of psychological (emotional), physical, medical, sexual, economic (financial), leisure, domestic nature, by a man or other family member, in order to humiliate the honor and dignity of the victim. Domestic violence against a woman of leisure nature in forcing (physical, mental influence) the victim to spend her vacation at the request of the tyrant is represented.

Keywords: violence; domestic violence; domestic violence against women.

A ктуальність дослідження. Сучасний соціум розглядає домашнє насильство над жінками як вид злочину, що не є настільки прийнятим усіма членами суспільства. Насильство над жінками у більшості випадків $є$ родинною таємницею, позаяк жінки, які стали жертвами, соромляться заявити про це.

Відповідно до даних ООН, кожного року понад 1,1 млн жінок України стають жертвами фізичної та сексуальної агресії і мовчать про це через тиск у родині. Мовчання жінок, над якими здійснюється будь-який вид насильства не дивує майже нікого.
На території України з давніх часів застосування будь-якого виду домашнього насильства над жінкою $є$ суто родинною справою, а ще гіршим це стає, коли насильство стає методом виховання і навчання дітей.

Український інститут соціологічних досліджень провів опитування, в ході якого з'ясувалося, що 27 \% жінок вважають проявом насильства образи, $32 \%$ так оцінюють приниження, а для $49 \%$ респонденток домашнє насильство - це винятково побої [10].

Актуальність означеної проблеми і аналіз 
статистичних даних дає нам можливість стверджувати, що сьогодні є недостатнє висвітлення проблеми домашнього насильства над жінками.

Мета статті - провести теоретичний аналіз історичного становлення і розвитку домашнього насильства над жінкам як наукового поняття.

Відповідно до поставленої мети, визначено завдання дослідження:

1. Здійснити історичний зріз стосовно виникнення домашнього насильства над жінками.

2. Охарактеризувати розвиток домашнього насильства над жінками.

3. Констатувати домашнє насильства над жінками як наукове поняття.

Розгляд насильства у родині проводився зарубіжними вченими та правозахисниками, зокрема Джейн Коннорс, Ребекою Кук, Ребекою Севал, Ендрю Бернес, Хилкою Пиєтіле, Катаріною Бартлет тощо. В українській правовій науці окремі дослідження цієї проблеми здійснювали А. Блага, В. Голіна, К. Левченко, А. Ноур, О. Руднєва, Г. Христова.

Виклад основного матеріалу. Згідно 3 опитуванням, проведеним у 2018 р. за підтримки Організації безпеки та співробітництва в Свропі (далі- ОБСЄ), можемо стверджувати про те, що дві третини (67\%) жінок у віці з 15 р. зазнали психологічного, фізичного або сексуального насильства з боку партнера або іншої особи. Близько половини жінок (50 \%) замовчують про наявну проблему домашнього насильства [10].

Свій початок родинне насильство над жінкою бере $з$ давніх часів. У багатьох джерелах, зокрема, міфах, легендах, ми можемо спостерігати домінуюче становище чоловіка над жінкою. Започаткувала цей процес саме релігія. У будь-якій релігії світу можемо знайти інформацію про те, що чоловік $є$ вищий над жінкою і має більше переваг у соціумі.

Можемо стверджувати, що саме так релігія виправдовувала соціальні ролі жінки як рабині, служниці, підлеглої. Виокремимо, що зважаючи на вплив релігії на статус жінки, існують два типи релігії (див. рис. 1).

Сучасний світ репрезентує нам безліч релігій, які змінили своє ставлення до жінок, але все ж таки визнають домінування чоловічої статі над жіночою. Не слід забувати про решту релігій, які підтримують фізичне покарання жінок, або навіть i їхню смерть при необхідності, особливо коли були вчинені ними гріховні діяння.

Важливість релігійних канонів можемо пояснити тим, що релігійна сфера у всій історії сприяла існуванню суспільних і державних утворень, установок і цінностей, які констатували прагнення володіти чоловіка над жінкою. Сьогодні велика кількість українців дотримуються релігійних норм більше ніж норм права. Наприклад, застосовувати фізичне насильство над жінками у разі скоєння ними гріха, нехтуючи нормою, яка категорично забороняє застосовувати фізичне насильства.

Дослідження агресії до жінок розпочалося 3 вивчення іiї сутності 3. Фройдом, який вважав, що агресивність, по суті, може бути не реакцією на подразнення, а $є$ постійно присутнім в організмі імпульсом, зумовленим природою людини. Проаналізувати взаємозв'язок агресивної поведінки та насильства у своїх роботах вдалося Е. Фромму [13]. Р. Берон і Д. Річардсон презентували систему соціального навчання i довели, що означений ними процес має специфічний характер міжособистісної взаємодії в сім'ях і призводить до поступового засвоєння і закріплення агресивних стереотипів поведінки, який повторюється у різноманітних ситуаціях міжособистісної взаємодії [6]

Варто відзначити теорію соціального навчання А. Бова, І. Грабської, О. Шинкаренко. Науковцями було виокремлено три підходи до проблеми насильства в сім'ї: соціально-історичний, системно-сімейний та індивідуально-психологічний $[5,9]$.

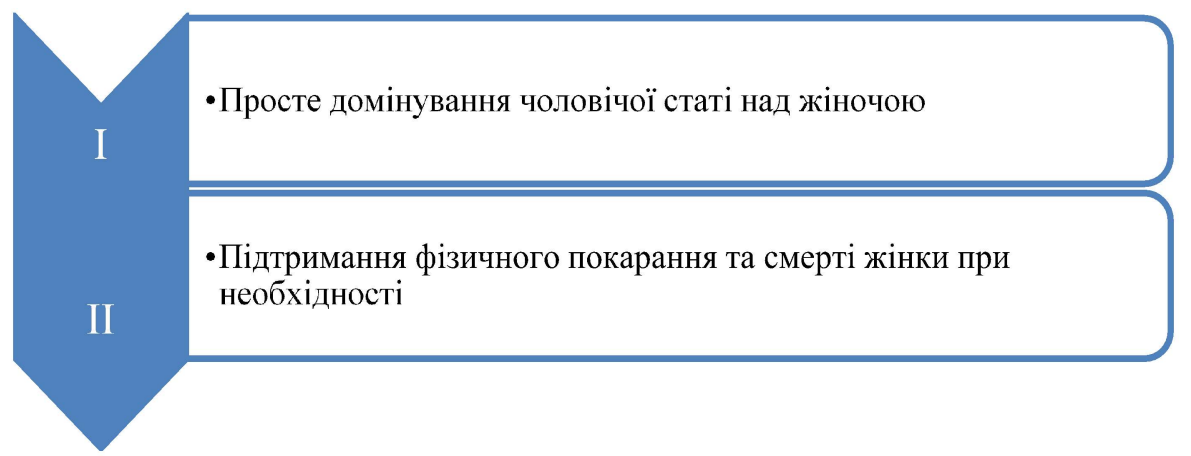

Джсерело: розроблено автором

Рис. 1. Ставлення релігії до жінок 
С. Шаргородська, провівши наукове дослідження, змогла констатувати, що домашнє насильство певні свідомі дії одного члена сім’і (партнера) проти іншого члена сім'ї (партнера), які порушують права і свободи людини, завдають шкоди фізичному, психічному, економічному, сексуальному здоровому існуванню [14].

У сучасному світі констатує Я. Юрків розгляд домашнього насильства як певні свідомі дії одного члена сім'ї стосовно іншого, якщо ці дії порушують конституційні права й свободи члена сім’ї як громадянина та завдають шкоду його фізичному, психічному або аморальному здоров'ю [15].

Зауважимо, що насильство - феномен складний, багатоаспектний. Загалом, поняття насильства несе чітко виражене негативно оцінене навантаження і вживається у дуже широкому значенні, включаючи усі форми фізичного, психологічного, економічного придушення, а також такі душевні якості, як брехня, ненависть, лицемірство, тощо [11]. При цьому, як зазначає Л. Кулик, під придушенням розуміється будь-яке обмеження умов особистого розвитку, причиною якого є діяльність інших людей або суспільних інститутів [11].

Уважаємо за необхідно розглянути наукові підходи до розуміння таких понять, як “насильство”, “агресія”, “примушення”, “жорстоке поводження з дітьми”, “катування”, “фізичний примус". Адже, як відомо, допоки відсутнє законодавче визначення того чи іншого поняття, немає і точного знання його істотності та критерію для відмежування від інших понять [1]. Слово “насильство” утворилося внаслідок злиття двох морфем: префікса “на” та кореня “сил(а)”, тобто дослівно воно означає “на силу”, застосування сили [2]. Своєю чергою, термін “сила" визначається як "здатність живих істот напруженням м'язів робити фізичні рухи, виконувати різні дії; фізична здатність або можливість робити, здійснювати що-небудь; фізичний вплив; насильство" [3]. Існує спеціальна наука, яка займається вивченням поняття насильства - віолентологія (від лат. violentia “насильство”).

Соціологія розглядає насильство як вид соціальної девіації і визначає його як явище дискримінації особи, утиск або обмеження ії прав і свобод. Необхідно зазначити, що більшість соціологічних теорій девіантної поведінки підкреслюють значну роль інтрапсихічних процесів, а також визнають вплив біогенетичних чинників на формування схильності до насильницької поведінки. Однак слід зазначити, що багато хто з вчених-соціологів об'єктом вивчення обирав, насамперед різноманітні форми колективного, соціального насильства, в яких основними детермінантами виступають соціальні умови та об'єктивні обставини. Економічна і соціальна нерівність породжує диференціацію суспільства на групи, суспільні класи i, як наслідок, суперечності і боротьбу між ними. Такий підхід до насильства характерний для багатьох соціологічних парадигм і наукових течій $[4,18]$.

Однією $з$ ознак домашнього насильства $\epsilon$ систематичність, тобто для того, щоби домашнє насильство стало кримінально караним діянням, воно має вчинятися з певною періодичністю. Як зазначає О. Степаненко, “систематичність згадується в контексті систематичного вчинення правопорушень, що потягли за собою адміністративні стягнення і свідчать про іii небажання стати на шлях виправлення. Відповідно до усталеної практики, систематичним вчиненням правопорушень вважається вчинення засудженим трьох і більше правопорушень, за які його було притягнуто до адміністративної відповідальності” [12].

Боротьба 3 домашнім насильством стала науковим поняттям, яке потребує комплексного різними галузями такими, як: соціологія, психологія, педагогіка, філософія, психіатрія. 3 виокремленням означеного нами поняття як наукової дефініції, вважаємо за необхідне виділити три основні етапи родинного насильства над жінками (рис. 2).

Перший етап - виникнення напруги у стосунках. Характеристикою означеного етапу є відносно спокійне реагування об'єкта насильства та його спроби поліпшити ситуацію. Незважаючи на спроби об'єкта насильства все налагодити, спостерігається постійний ріст напруги, який формує психічно-неврівноваженого об'єкта насильства.

Наступним етапом є сам прояв насильства, так зване “гостре насильство". Цей етап характеризується беззаперечним визнанням суб'єкта насильства свого гніву, а об'єктом вплив на нього акту насильства. Як наслідок виникає спроба змінити акцент суб'єктом насильства 3 подальшим його переведенням на сам об'єкт.

Фінальним етапом є “Медовий місяць”, який можемо охарактеризувати двома шляхами: визнання суб'єктом насильства своєї провини або психологічний тиск, який закріплює за об'єктом насильства почуття провини за акт насильства.

На нашу думку, домашнє насильство над жінкою - це багаторазове застосування сили психологічного (емоційного), фізичного, 


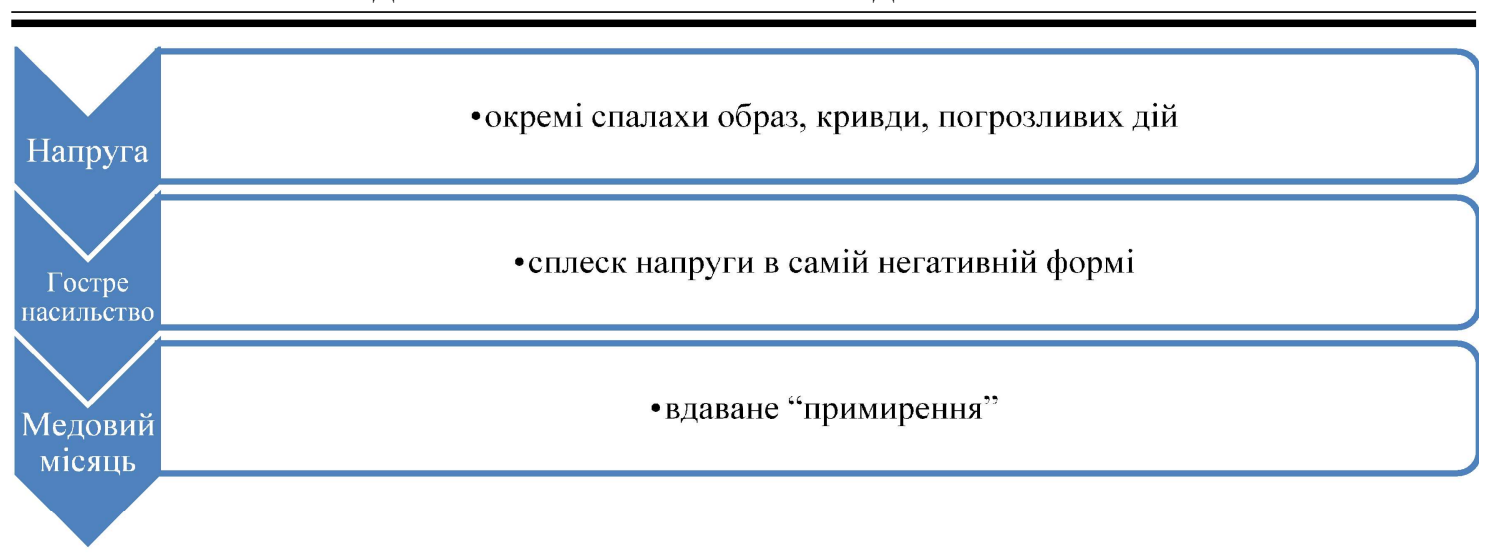

\section{Джсерело: опрацьоване автором}

медичного, сексуального, економічного (фінансового), дозвіллєвого, побутового характеру, чоловіком чи іншим членом родини, з метою приниження честі та гідності жертви. Насильство вказує на протиправність, дисбаланс сили і влади тирана та неспроможність жертви насилля захистити себе та дати відсіч.

Практично в усіх таких сім'ях етапи заспокоєння та примирення 3 часом скорочуються, а випадки насильства стають все частішими. Виникає кризова ситуація. Настає момент, коли жертва чи жертви вже більше не можуть жити в такій ситуації. Вони більше не погоджуються терпіти знущання, починають усвідомлювати свої права і можливості, не хочуть страждати самі і не хочуть, щоб страждали діти. На жаль, тут вони стикаються зі значними труднощами [7].

Домашнє насильство над жінкою дозвіллєвого характеру вбачаємо у примушуванні (фізичний, психічний вплив) жертви проводити свій відпочинок за бажанням тирана. Як правило, кривдник у виборі дозвілля керується знаннями про фобії жертви (соціальні, конкретні, агорафобію). Знаючи про хворобливі страхи дружини щодо висоти, води та ін., тиран пропонує роуп-джампінг, банджі-джампінг, скелелазіння, рафтинг, стрибки з парашутом та ін.

Наслідками таких актів домашнього насильства над жінками можуть стати, зокрема: втрата соціальних контактів з родичами, друзями, гостре відчуття самотності та ізольованості; уникання погляду в очі, приниженість у поведінці, квапливість; суїцидальні наміри, погрози позбавити себе життя; почуття провини за отримані фізичні ушкодження; звуження свідомості, нездатність адекватно оцінювати власне майбутнє, свої вчинки та вчинки інших людей, поєднання підозрілості з безмежною довірливістю.
Уважаємо за доцільно виокремити три групи основних факторів, зокрема: перша група пов'язана з об'єктами, котрі вчиняють насилля, друга - 3 жертвами насилля, а третя стосується і тих, і інших. До факторів ризику, як насильства 3 боку інтимного партнера, так і сексуального насилля, включають: низький рівень освіти; жорстоке поводження в дитинстві; спостережуване насильство у відносинах між батьками; антисоціальний розлад особистості; вживання алкоголю; терпимість до домашнього насилля 3 боку суспільства; гендерні нерівності тощо. Крім того, може спрацьовувати механізм “перенесення”, наприклад, чоловіки, які мали численні сексуальні стосунки до початку сімейного життя та продовжують в тому ж дусі і після, можуть також підозрювати своїх дружин у нерозбірливих сексуальних зв'язках, що також може викликати прояви насильства щодо жінки. Фактори, безпосередньо пов'язані з насильством з боку інтимного партнера, включають: минулий досвід насильства; розбіжності між подружжям і незадоволеність в подружньому житті; труднощі в спілкуванні між партнерами. Фактори ризику, характерні для здійснення сексуального насильства, включають: віру в честь сім'ї і сексуальну чистоту; ідеології домінуючого становища чоловіків в сексуальних відносинах; слабкі правові санкції за сексуальне насильство.

Наголосимо що, на превеликий жаль, домашнє насильство не має ні соціальних, ні національних меж, і трапляється у всіх суспільних прошарках, незалежно від рівня освіти чи матеріальної ситуації. Насильство з боку інтимного партнера (фізичне, сексуальне, емоційне) і сексуальне насильство призводять до серйозних короткочасних і тривалих проблем фізичного, психічного, сексуального та репродуктивного здоров’я у жінок. Ці форми насильства також позначаються на їх дітях і породжують значні 
соціальні та економічні втрати для жінок, їх сімей, та суспільства.

Враховуючи вищеописане, хочемо зробити висновок, що становлення домашнього насильства над жінками як наукового поняття відбулося з виникненням необхідності подолати проблему. Саме тому ця дефініція і стала предметом вивчення багатьох наук, зокрема соціальної педагогіки. Домашнє насильство над жіночою статтею є значним процесом сьогодні, який зводить нанівець суспільні канони, знищує моделі взаємопорозумінь, спотворює ціннісні орієнтації, спричиняє, зароджує масові психологічні комплекси неповноцінності, жорстокості, агресії, ненависті і є серйозною перешкодою для досягнення рівноправності та дотримання прав жінок у сучасному суспільстві.

Експерти вважають, що жертв набагато більше, тому що не всі випадки домашнього насильства стають приводом для відкриття карних справ. Крім того, в нашій культурі існує традиція замовчувати такі проблеми, як мовиться “не треба виносити сміття з хати”. Таким чином, більша частина випадків щодо сімейного насилля залишається поза увагою правоохоронців.

\section{ЛІТЕРАТУРА}

1. Аванесов Г. А. Криминология. Горький, 1984.560 с.

2. Алексеев А. И. Криминология: курс лекций. Москва: Щит-М, 1998. 340 с.

3. Алиев Г. А. Криминологическая характеристика и предупреждение органами внутренних дел убийств, совершенных лицами, отбывшими наказание в виде лишения свободы: автореф. дис. ... к.ю.н.:12.00.08. Москва, 1998. $21 \mathrm{c.}$

4. Байда А. О. Проблеми кримінальної відповідальності за домашне насильство. Питання боротьби зі злочинністю, 2017. № 32. С. 79-94

5. Бова А. А. Модель факторів, що обумовлюють насильство в сім'ї. Украӥнський соиіум, 2005. №1. С.15-25.

6. Бэрон Р., Ричардсон Д. Агрессия. СПб: Питер, 2001. 352 с: ил. (Серия “Мастера психологии”. ISBN 5-88782294-5

7. Бурлаков В. Н. Криминология: учеб. для юрид. Вузов. Санкт-Петербург: С. Петербург. ун-т МВД России, 1999.608 с.

8. Горшкова О. А. Педагогічна діагностика старших класів, що вчаться, при організації реабілітаційної роботи. 3б. Проблеми особистості, профілактика відхилень у ї̈ розвитку. Москва, Архангельськ, 1993. 234 с. Библиогр.: с. 231-234

9. Грабська І. А. Насильство в подружніх відносинах. Практична психологія та соиіальна робота. 1998. № 9.

10. Домашнє насильство в Україні : скільки в країні жертв і що загрожує кривдникам. URL: https:// ukr.segodnya.ua/ukraine/domashnee-nasilie-v-ukrainekto-stanovitsyazhertvami-i-chto-grozit-obidchikam1099013.html
11. Кулик Л. М. Ознаки насильницької злочинності. Держава та регіони: серія “Право”, 2009. № 2. С. 6569.

12. Степаненко О. В. Систематичність як ознака домашнього насильства. Правові та інституційні механізми забезпечення розвитку України в умовах європейської інтеграції : матеріали Міжнародної науково-практичної конференції (м. Одеса, 18 травня 2018 р.) : у 2 т. Т. 2 / відп. ред. Г.О. Ульянова. Одеса : Видавничий дім “Гельветика", 2018. С. 204-206.

13. Фромм Э. Миссия Зигмунда Фрейда. Анализ его личности и влияния = Sigmund Freud's Mission. An Analysis of His Personality and Influence (1959) / Пер. А. М. Руткевича. Москва: Весьмир, 1990.144 с. ISBN 57777-0002-0.

14. Шаргородська С. Насилля в сім'ї: види, наслідки, шляхи подолання. Сойіальний педагог. 2007. № 2. С. 14-16.

15. Юрків Я. І. Насильство дітей у сім'ї як соціальнопедагогічна проблема. Науковий вісник Ужгородського університету : Серія: Педагогіка. Соціальна робота. Ужгород : Говерла, 2013. Вип. 28. C. $185-189$.

\section{REFERENCES}

1. Avanesov, H. A. (1984). Krymynolohyia [Criminology]. Horkyi, 560 p. [in Russian].

2. Alekseev, A. Y. (1998). Krymynolohyia: kurs lektsyi [Criminology: a course of lectures]. Moscov, 340 p. [in Russian].

3. Alyev, H. A. (1998). Kriminologicheskaya kharakteristika i preduprezhdenie organami vnutrennikh del ubiystv, sovershennykh litsami, otbyvshimi nakazanie $\mathrm{v}$ vide lisheniya svobody [Criminological characteristics and prevention by the internal affairs bodies of murders committed by persons who have served a sentence in the form of imprisonment]. Extended abstract of candidate's thesis. Moscov, 21 p. [in Russian].

4. Baida, A. O. (2017). Problemy kryminalnoi vidpovidalnosti za domashnie nasylstvo [Problems of criminal liability for domestic violence]. Issues of combating crime, no. 32. pp. 79-94. [in Russian].

5. Bova, A. A. (2005). Model faktoriv, shchoobumovliuiutnasylstvo $\mathrm{v}$ simi [Model of factors that cause domestic violence]. Ukrainian Society, no.1. pp.1525. [in Ukranian]

6. Beron, R. \& Richardson, D. (2001). Ahressyia [Aggression]. Master of Psychology Series. St.Petersburg, 352 p. ISBN 5-887-82294-5 [in Russian].

7. Burlakov, V. N. (1999). Krymynolohyia: ucheb. dlia yuryd. Vuzov [Criminology: textbook. for jurid. University]. St.Petersburg, 608 p. [in Russian].

8. Horshkova, O. A. (1993). Pedahohichna diahnostyka starshykh klasiv, shcho vchatsia, pry orhanizatsii reabilitatsiinoi roboty [Pedagogical diagnosis of high school students in the organization of rehabilitation work]. Coll. Problems of personality, prevention of deviations in its development. Moscov, 234 p. Byblyohr.: pp. 231234 [in Ukrainian].

9. Hrabska, I. A. (1998). Nasylstvo v podruzhnikh vidnosynakh [Violence in marital relations]. Practical Psychology and Social Work. No. 9. [in Ukrainian]. 
10. Domashnie nasylstvo v Ukraini : skilky v kraini zhertv $i$ shcho zahrozhuie kryvdnykam [Domestic violence in Ukraine: how many victims in the country and what threatens offenders]. Available at: https://ukr.segodnya.ua/ ukraine/domashnee-nasilie-v-ukraine-ktostanovitsyazhertvami-i-chto-grozit-obidchikam1099013.html [in Ukrainian].

11. Kulyk, L. M. (2009). Oznaky nasylnytskoi zlochynnosti [Signs of violent crime]. State and Regions: Law Series, no.2. pp. 65-69. [in Ukrainian].

12. Stepanenko, O. V. (2018). Systematychnist yak oznaka domashnoho nasylstva [Systematics as a sign of domestic violence]. Odesa, pp. 204-206. [in Ukrainian].

13. Fromm, E. (1990). Myssyia Zyhmunda Freida.
Analyz eho lychnosty y vlyianyia $=$ Sigmund Freuds Mission. An Analysis of His Personality and Influence [Sigmund Freud's mission. Analysis of his personality and influence $=$ Sigmund Freud's Mission]. Moscov, $1990.144 \mathrm{p}$. ISBN 5-7777-0002-0. [in Russian].

14. Sharhorodska, S. (2007). Nasyllia v simi : vydy, naslidky, shliakhy podolannia [Domestic violence: types, consequences, ways to overcome]. Social pedagogue. No. 2.pp. 14-16. [in Ukrainian].

15. Iurkiv, Ya. I. (2013). Nasylstvo ditei u simi yak sotsialno-pedahohichna problema [Violence of children in the family as a socio-pedagogical problem]. Scientific Bulletin of Uzhgorod University: Series: Pedagogy. Social work. Uzhhorod, 2013. Vol. 28. pp. 185-189. [in Ukrainian].

Стаття надійшла до редакції 27.04.2021

УДК 378.091.3:373.5.011.3-051]:78

DOI:

Чжоу Сіньюй, аспірант кафедри педагогіки мистеитвва та фортепіанного виконавства Національного педагогічного університету імені М.П. Драгоманова

\section{ПРИНЦИП ОПОРИ НА ЄВРОПЕЙСЬКИЙ МУЗИЧНО-ІСТОРИЧНИЙ ДОСВІД У ФОРМУВАННІ ПОЛІФОНІЧНОГО СЛУХУ СТУДЕНТІВ 3 КНР У ПРОЦЕСІ ФОРТЕПІАННОГО НАВЧАННЯ}

У статті актуалізовано проблему формування поліфонічного слуху студентів з КНР у процесі фортепіанного навчання. Здійснено огляд сучасних наукових робіт китайських авторів з метою обтрунтування доцільності запропонованого принщииу. Виявлено, щуо означений принцип розглядався авторами в інших проєкиіях з підкресленням взаємодії культур. Виявлено ознаки європейського музично-історичного досвіду та його вплив на формування майбутнього вчителя музичного мистецтва. Запропоновано педагогічні умови, створення яких уможливить реалізацію зазначеного принцину. Акиентовано увагу на необхідності розвитку поліфонічного мислення студентів, а також на опануванні прийомів виконання поліфонії різних епох, стилів і жанрів.

Ключові слова: музично-історичний досвід; поліфонічне мислення; фортепіанне навчання; начіональні традииї музичної освіти; майбутній вчитель музичного мистеитвва.

Jim. 6.

Zhou Xinyu, Postgraduate Student of the Pedagogy of Art and Piano Performance Department Mykhaylo Drahomanov National Pedagogical University

\section{THE PRINCIPLE OF RELIANCE ON EUROPEAN MUSIC-HISTORICAL EXPERIENCE IN THE FORMATION OF CHINESE STUDENTS' POLYPHONIC HEARING IN THE PROCESS OF PIANO LEANING}

The article actualizes the problem of forming polyphonic hearing of Chinese students in the process of piano learning. The author carries out the review of modern scientific works of Chinese authors to substantiate the feasibility of the proposed principle. It was found that young Chinese researchers who studied the system of Ukrainian music and pedagogical education (Wing Bin, Wang Ying Yun, Lan Xijun, Ding Yun, Fu Xiaojing, Hou Yue, Chen Kai, Shuguang) pay attention to the prospects of studying the views of famous European musicians for modern musical education and the formation of pianistic experience. In their research, they highlight the most important principles and methods of teaching for Chinese music pedagogy; and apply time-tested forms of organization of executive activity. The importance of national and world orientation of piano teacher training in music is emphasized.

The signs of European music-historical experience in the context of the formation of polyphonic hearing are revealed: awareness of the importance of previously unknown musical knowledge, methods, and techniques of polyphonic technique; the possibility of applying the acquired knowledge and skills in their own musical performance; correspondence of polyphonic thinking to stylistic features of musical works.

Pedagogical conditions are proposed, the creation of which will enable the implementation of this principle. Emphasis is placed on the need to develop the students' polyphonic thinking, as well as on mastering the techniques of performing polyphony of different eras, styles, and genres.

(C) Ч. Сіньюй, 2021 